Geosistemy perehodnykh zon = Geosystems of Transition Zones / Геосистемы переходных зон

Content is available under the Creative Commons Attribution 4.0 International License (CC BY 4.0)

2021, vol. 5, No. 1, pp. 67-71

URL: http://journal.imgg.ru/archive.html ; https://elibrary.ru/title about.asp?id=64191

https://doi.org/10.30730/gtrz.2021.5.1.067-071

\title{
An algorithm for processing ice areas by Earth remote sensing data (by the example of MASIE-NH data)
}

\author{
Vasily S. Nikonov, vasiliyni@yandex.ru
}

Graduate student, Sakhalin State University, Technical Oil and Gas Institute, Yuzhno-Sakhalinsk, Russia

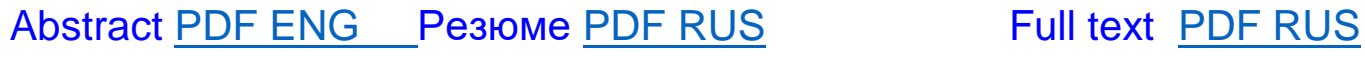

Abstract. An algorithm was developed to automate processing of large datasets of Earth remote sensing. The algorithm was developed and implemented in the form of an M-Processor program in the Python programming language using the modules of the ArcGIS Desktop 10.2 software, which allows complex calculations without spending additional time on programming and reduces the number of manipulations for calculating separate desired characteristics. The implementation of the developed algorithm is considered on the example of calculating the numerical characteristics of the ice area in the Sea of Okhotsk according to the data of the Multisensor Analyzed Sea Ice Extent - Northern Hemisphere (MASIE-NH) with a spatial resolution of 1 and $4 \mathrm{~km}$ and an ice-cover zoning mask.

\section{Keywords:}

sea ice, Earth remote sensing, geographic information systems, software, Multisensor Analyzed Sea Ice Extent - Northern Hemisphere

For citation: Nikonov V.S. An algorithm for processing ice areas by Earth remote sensing data (by the example of MASIE-NH data). Geosistemy perehodnykh zon = Geosystems of Transition Zones, 2021, 5(1), pp. 67-71. (In Russ., abstr. in Engl.). https://doi.org/10.30730/gtrz.2021.5.1.067-071

Для цитирования: Никонов В.С. Алгоритм обработки площадей льда по данным дистанционного зондирования Земли (на примере данных MASIE-NH). Геосистемы переходных зон, 2021, 5(1): 67-71. https://doi.org/10.30730/gtrz.2021.5.1.067-071

\section{References}

Nikulina I.V., Nikonova E.V., Romanyk V.A., Dorofeeva D.V. 2020. Organization of storage and processing of spatial hydrometeorological data based on web geoinformation platforms. In: Current trends and prospects for the development of hydrometeorology in Russia: Materials of the III All-Russian Scientific and Practical Conference, Irkutsk, November 25-27, 2020. Irkutsk: IGU Publ., p. 360-365. (In Russ.).

Minervin I.G., Romanyuk V.A., Pishchalnik V.M., Truskov P.A., Pokrashenko S.A. 2015. Zoning of the ice cover of the Sea of Okhotsk and the Sea of Japan. Vestnik Rossiyskoy akademii nauk = Herald of the Russian Academy of Sciences, 85: 132-139.

Shumilov I.V, Pispchalnik V.M., Minervin I.G. 2017. About new version of the "Ice" software package. Materials of the International conference "InterCarto. InterGis", Moscow: Moscow University Publ., 23: 250-256. (In Russ.).

https://doi.org/10.24057/2414-9179-2017-2-23-250-256 